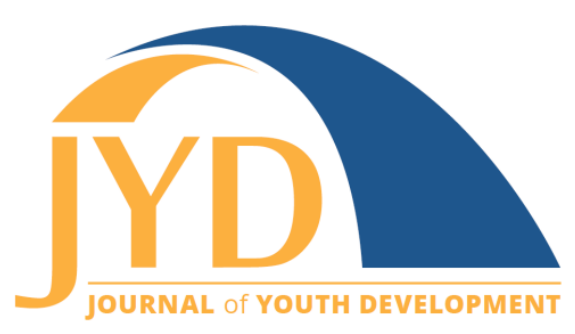

http://jyd. pitt. edu/ | Vol. 14 Issue 1 DOI 10.5195/jyd.2019.581 | ISSN 2325-4017 (online)

\title{
Linking Experiential Workshops and Increased STEM Interest Among First- and Second- Generation Latino Youth
}

\section{Jeff Sallee}

Oklahoma State University

jeff.sallee@okstate.edu

Ronald B. Cox

Oklahoma State University

r.cox@okstate.edu

\section{Rita Flores}

Oklahoma State University

rita.flores@okstate.edu

\section{Steven R. Cooper}

Oklahoma State University

steven.cooper@okstate.edu

\section{Belinda I. Gomez}

U.S. Army Institute of Surgical Research

belinda.i.gomez.ctr@mail.mil

\section{Craig A. Gifford}

New Mexico State University

cgifford@nmsu.edu

\section{Jennifer A. Hernandez-Gifford}

New Mexico State University

jgifford@nmsu.edu

(c) $\mathrm{EY}$ New articles in this journal are licensed under a Creative Commons Attribution 4.0 License. This journal is published by the University Library System, University of Pittsburgh and is cosponsored by the University of Pittsburgh Press. The Journal of Youth Development is the official peer-reviewed publication of the National Association of Extension 4-H Agents and the National AfterSchool Association. 


\section{Abstract}

Extension outreach professionals are searching for new methods to target the growing population of Latino students. Oklahoma State University faculty in the Animal Science department and the 4-H Youth Development program partnered to sponsor a 4-H STEM Institute designed to promote science, technology, engineering, and math to Latino students in the Unidos Se Puede program. The STEM Institute was designed to introduce the Latino youth to college life and STEM based career opportunities. The program was evaluated utilizing the 4-H Common Measures Science instruments. The results indicate a positive impact on the youths' perception of STEM as a career option. The students' increase in selfefficacy predicts the students will increase their persistence in the subjects of science and math (Simpkins, Davis-Kean, \& Eccles, 2006). Increased persistence in science and math leads to increased success in post secondary STEM studies and occupations.

Key words: STEM, Latino, Hispanic, animal science, biotechnology, digital media

\section{Introduction}

There is an urgent need to increase workers in the fields of science, technology, engineering, and mathematics (STEM) in the United States (National Academy of Sciences, 2007; National Science Board, 2018; Rice, Rugg, \& Davis, 2016). The U.S. Bureau of Labor Statistics projects the U.S. labor force will experience a shortfall of approximately one million college graduates contributing to the skilled workforce by 2025 (Johnson \& Sengupta, 2009). Despite the growing need, students in the United States are less likely than students in other countries to major in a STEM-related field, resulting in 35\% of the Ph.D. holders in the U.S. STEM workforce being foreign-born (Atkinson \& Mayo, 2011). Minorities and women have been historically underrepresented in STEM fields. For example, the percentage of Latinos in the U.S. labor force grew from three percent in 1970 to $15 \%$ in 2011, yet Latinos accounted for only seven percent of STEM-related jobs (Landivar, 2013). The lack of Latinos in STEM-related industries is largely a result of gaps in academic achievement and lower degree completion rates. Because employment opportunities in STEM-related jobs and the Latino population are both expected to grow significantly over the next 30 years, it is paramount these disparities be successfully addressed to increase America's ability to compete globally (Hagedorn \& Purnamasari, 2012; Litow, 2008; Rochin \& Mello, 2007; Scott, 2010).

The acute underrepresentation of minorities in STEM disciplines is not necessarily due to a lack of interest. One study reported eighth-grade Latino students have the same attitudes as other students toward science and math as a career option (Arbona \& Nora, 2007), but these attitudes do not translate into college enrollment, and particularly not into STEM majors. Latinos were underrepresented by more than $50 \%$ in undergraduate engineering programs as 
STEM Workshops and Interest Among Latino Youth

compared to their representation in the U.S. population of 18- to 24-year-olds (National Science Foundation, 2012). Latinos are also underrepresented in gifted education programs at these same levels (U.S. Department of Education, 2008), suggesting the talents of high-ability minority students are not being developed. Ensuring student readiness for postsecondary STEM programs requires exposure to appropriate course content in high school (Lynch, 2011). However, Latino students are significantly less likely than Caucasian students to take the optional science and math courses that would prepare them for success (Cole \& Espinoza, 2008; Crisp \& Nora, 2012).

\section{How Students Choose STEM Courses}

In an effort to better understand student choices around school coursework and career choice, Eccles and colleagues (1983) developed the expectancy value theory of achievement-related choices. According to this model, students' decisions to enroll in math and science courses are determined by two processes that work in concert: (a) student assessments or expectations of how successful they will be and (b) the relative value they assign to their available options. Expectations for success in science and mathematics are represented by a child's sense of selfefficacy in science and mathematics, which predicts student persistence in those subjects, even after controlling for achievement and socio-economic status (Simpkins, Davis-Kean, \& Eccles, 2006). In a study conducted among predominantly Caucasian students, Mau (2003) found mathematics self-efficacy and academic proficiency of eighth-grade students predicted likeliness to persist in aspiring to a science or engineering career. Among eighth-grade Mexican-American students (Navarro, Flores, \& Worthington, 2007) and inner-city, low-socio-economic-status students (Fouad \& Smith, 1996), mathematics and science self-efficacy was associated with career-related goals and intentions.

Although expectations for success and personal efficacy predict the selection of STEM-related coursework and subsequent career choice, the value students attach to perceived occupational characteristics is also an important determinant of involvement in STEM-related fields. According to Eccles (2009), the subjective task value describes the relative importance of an option as determined by students in selecting coursework leading to an occupation. The subjective task value is described by Eccles in terms of four components: (1) the intrinsic value and enjoyment of the task, (2) the utility of the task related to facilitating the student's future goals, (3) the value of the activity based on its consistency with student self-image and personal and collective identity, and (4) the relative opportunity cost of the activity determined 
STEM Workshops and Interest Among Latino Youth

by perceptions of time taken away from other activities or the potential meaning of the behavior in terms of personal and social identity.

The expectancy value theory goes on to suggest individuals choose from several options, but they do not objectively consider all available options. Many options are never considered because the individual is unaware of the option, has inaccurate information about the option or his or her opportunity to achieve the option, or believes the option does not fit his or her socialor gender-role schema. For example, the lack of same-race role models or well-known historical figures in STEM fields may lead minority students to believe they must be assimilated and surrender their racial or ethnic identity to succeed (Cooper, 2011). This may lead minority students to assess science and mathematics coursework as having a low utility value and prevent them from considering these options as reasonable possibilities for their personal goals (Archer et al., 2010; Archer, Hollingworth, \& Halsall, 2007; Hines, 2003). Collective social identity and peer group membership have been found to be predictive of math motivation and the popularity of engaging in math and science (Frank et al., 2008). For example, students belonging to a peer group that encourages science achievement are associated with more positive attitudes toward science (Stake, 2006) and are more likely to imagine themselves as future scientists (Stake \& Nickens, 2005).

In summary, the pathway to STEM-related careers consists of a series of choices and achievements that begins in childhood and adolescence. These choices and achievements are directly related to student expectation for success and the value attributed to various options perceived as available. These factors are influenced by cultural norms, social experiences, aptitudes, and genetics (Eccles, Wigfield, \& Schiefele, 1997). Together, these findings suggest the motivation of Latino youth toward coursework in mathematics and science could be significantly altered through a brief intervention increasing student expectation for success and the value they attribute to a potential career in a STEM-related field. One such intervention is the 4-H STEM workshop provided as a component of the larger Unidos Se Puede (United We Can, "Unidos") program.

\section{The Unidos Se Puede Program}

Due to the barriers and hardships associated with arriving in communities without the social infrastructure to meet their needs, immigrant Latino youth are at a much higher risk than other ethnic groups for poor academic performance and school dropout. Unidos (pronounced "oonee-dos") is a Children, Youth and Families at Risk (CYFAR) 4-H program designed to build 
resilience in Latino families through intensive 24-month support (two school years) via three major components:

1. Parental involvement is increased through a 5-week Unidos Family Workshop Series, plus monthly family nights thereafter. This element helps families gain the knowledge, skills, and resources they need to effectively engage in their adolescent's academics and make college access a realistic family goal. Each lesson targets youth and parent self-efficacy through the liberal use of reflection points, role-plays, and activities designed to help participants build resilience through the integration of advocated practices into daily life. The intervention includes strategies and activities that create cues to action to promote academic performance. Monthly family night activities reinforce the 5-week workshop series, build family communication and cohesion through interactive activities, promote trust between Unidos personnel and families, expose youth and families to community resources and professionals, and allow for peer relations to begin to form.

2. Ethnically-matched university students serve as success coaches to youth. The purpose of a success coach is to foster self-efficacy and resilience in youth by developing a personal success plan focused on educational goals and based on a complete assessment of needs and assets. Coaches use data provided by the school on absences, tardiness, grades, and behavior problems to set goals, continually monitor progress, and help youth develop problem-solving skills to address barriers. Coaches emphasize the importance of a strong parent-adolescent relationship and help youth cultivate other skills and attributes of positive youth development (e.g., personal care, study habits, time management). Success coaches maintain regular contact with parents to encourage and empower their involvement in their child's academic achievement. Because coaches are near-peer mentors actively enrolled in university studies, they serve as role models and can help demystify the process of attending secondary education.

3. Positive peer affiliations are promoted through weekly 4-H Clubs throughout the summer. Unidos youth participated in eight weekly activities during the summer designed to provide a sense of belonging among like-minded peers and competency in life skills as well as increased motivation to pursue higher education by exposing youth to professionals in diverse fields of science and technology. A final outing consisted of a 2-day trip to Oklahoma State University (OSU) where youth were encouraged to envision themselves completing a 4-year degree and to participate in hands-on science activities including DNA sequencing through the Animal Science Department and digital media through the Agricultural Communications Services unit. 
The purpose of this article is to explore the effects of the on-campus 4-H STEM workshop within the Unidos program. The 4-H STEM workshop was specifically designed to increase motivation to pursue a career in a STEM-related field among early adolescent Latino youth. We hypothesized Unidos youth would increase in their perceived expectations for success in STEMrelated activities and in the value they attribute to STEM-related activities as a result of attending the 4-H STEM workshop.

\section{The Unidos 4-H STEM Workshop Description}

4-H developed a focus on STEM education in response to the diminishing number of high school graduates pursuing careers in science, engineering, or other related professions. School administrators from two junior high schools in an urban school district in the southern U.S. identified students who qualified for the Unidos 4-H program based on their academic struggles and their high risk for dropping out of school. In partnership with the schools, the 4-H Youth Development Program uses an educational, service-based approach to encourage youth to explore and pursue higher education in scientific fields and continue on into their professional careers (Sallee \& Peek, 2014). The Unidos 4-H STEM Institute allowed youth and adults to work with university faculty on 2-day training tracks focused on digital media and animal science biotechnology. The STEM Institute offered the Unidos students an opportunity to live in the dorms, dine in the student union, and interact with college professors and Latino graduate students. The goal behind exposing these youth to the whole college experience was to make the idea of continuing on toward higher education-specifically pursuing a degree or a career in a STEM field-a possibility.

This program offered two training opportunities for students, each student participated in only one of the two tracks offered. One track focused on digital media and the other on animal science-based biotechnology. Along with providing the Unidos students with a preview of college life, both STEM-based tracks included lectures and a variety of hands-on lab activities. A detailed schedule of both tracks can be found in the Appendix.

The digital media training offered students the chance to work with video and photography equipment, and learn some of the techniques used in creating digital media. They were taught how to plan, light, and edit a video. The participants were challenged to develop a video inspired by their experiences on the OSU campus. The Unidos students then had the opportunity to film, edit and present their digital media creations to their peers. The OSU 
Animal Science faculty designed a unique experience to promote science discovery through hands-on experiences.

The students participating in the biotechnology workshop were exposed to research techniques and introduced to the basic concepts of biology. These activities enabled students to identify parentage/relationship of a group of young horses to several potential sires (stallions). The students predicted which stallion fathered the offspring based on the horse's appearance (phenotype). Next, DNA was collected from horsehair follicles from the manes of horses located at the OSU Horse Farm. The students then began the isolation of DNA. During this process, the students learned how to use air-displacement pipets and were introduced to the sophisticated lab techniques of polymerase chain reaction (PCR) and DNA sequencing. Finally, students compared their prediction to the actual DNA profile.

The animal science biotechnology track was led by two female Ph.D. graduate students and a female associate professor from the Department of Animal Science, all three of whom were Latino. As of 2012, Latina women represented only three percent of all bachelor's degrees and one percent of all master's and doctoral degrees earned in STEM-related subjects in the United States (National Center for Education Statistics, 2011). As for faculty, Latinas made up less than four percent of the nation's faculty in higher education institutions (National Center for Educational Statistics, 2011). These workshop presenters provided a unique opportunity for the underrepresented youth to identify with individuals of similar background who are pursuing and/or have attained a science degree in higher education. The Unidos students were encouraged to ask questions and be as hands-on as possible so they could better understand and retain the lessons.

Following the lab-based activities on day 1 of the workshop, participants from both tracks were given the opportunity for a hands-on horse experience. Students spent an evening at the OSU Animal Science Arena under the supervision of an OSU equine professor and equine students. The students were encouraged to ride horses and participate in roping demonstrations. For many of the Unidos students, this was their first direct interaction with a large domestic animal. The horse experience was the highlight of the 2-day workshop for many students. 


\section{Methodology}

\section{Participants}

The participants were 21 students drawn from a larger demonstration project targeting eighth grade Latino students from a southern urban school district who were at risk for poor academic achievement (see Table 1 for basic demographic information). By attending the free Unidos 4-H summer program, participants self-selected into the study.

Table 1. Unidos Student Demographic and History

\begin{tabular}{|c|c|c|c|}
\hline \multicolumn{2}{|l|}{ Characteristic } & \multirow{2}{*}{$\begin{array}{c}\text { Number of } \\
\text { participants } \\
17\end{array}$} & \multirow{2}{*}{$\begin{array}{c}\text { Percentage } \\
81 \%\end{array}$} \\
\hline Age range & $13-15$ years & & \\
\hline & $16-19$ years & 4 & $19 \%$ \\
\hline Race & Hispanic/Latino & 21 & $100 \%$ \\
\hline \multirow[t]{2}{*}{ Gender } & Female & 7 & $33.3 \%$ \\
\hline & Male & 14 & $66.6 \%$ \\
\hline \multirow[t]{3}{*}{ Years in 4-H } & This is my first year & 14 & $66.6 \%$ \\
\hline & This is my second year & 6 & $28.6 \%$ \\
\hline & Three or more years & 1 & $4.8 \%$ \\
\hline \multirow[t]{2}{*}{ STEM workshop track } & Animal Science Biotechnology & 9 & $42.9 \%$ \\
\hline & Digital Media & 12 & $57.1 \%$ \\
\hline
\end{tabular}

\section{Measures}

Students were administered a pretest and posttest immediately preceding and following the STEM workshop. The National 4-H Common Measures Instrument 1.0 for Science (CMIS) Grades 8-12 was used to evaluate their experience and the knowledge gained during the STEM workshop. The response set for the six-item National 4-H Common Measures Instrument for Science was a 4-point Likert-type scale ranging from 1 (strongly agree), to 4 (strongly disagree), lower scores indicate more interest in science (items are listed in Table 2). For ease of interpretation, we reversed these scales: higher scores indicate a higher interest in science throughout the remainder of this article. 


\section{Results}

Results of the pre-workshop and post-workshop tests were collected from all 21 Latino students who participated in the STEM workshop. Pretest scores were collected upon arrival to the workshop and posttest scores were collected after the last session of the workshop. To assess for student response to the workshop, we used a two-step process. First, items were summed to create a composite score for the 4-H CMIS. The range was from 6 to 24 with higher scores indicating a more favorable response. A paired sample $t$-test was used to estimate mean differences before and after the workshop on the 4-H CMIS. Second, to examine in what ways the workshop impacted the students, we ran a series of paired sample $t$-test on each item of the 4-H CMIS. Because of the relatively small sample size $(N=21)$ we set $a=0.06$ as statistically significant for $p$-values. Additionally, because we hypothesized that the workshop would have a positive impact on youth attitudes toward science, a 1-tailed test for significance was used for the individual items. All data were analyzed using SPSS software.

To approximate a test of the expectancy value theory of achievement-related choices assertion that students' decisions to enroll in math and science courses are determined by how successful they believe they will be, we created a STEM-efficacy scale by summing items 1, 4, 5, and 6 on the 4-H CMIS. We then tested the correlation between the STEM-efficacy scale and item 2, "I would like to have a job related to science," as a proxy for student decision to enroll in math and science courses.

As shown in Table 2, students responded favorably to the STEM activities. Significant increases from pre- to post-workshop were reported on the 4-H CMIS and for each of the individual items. Effect sizes as estimated by Cohen's $d$ ranged from small (.38) to medium (.64). Additionally, findings from our correlation analyses confirm the expectancy value theory of achievement-related choices for Latino students $(r=.44, p=.05)$ 
Table 2. Student Perspective on Science Pre- and Post- Unidos Sponsored STEM Workshop

\begin{tabular}{|l|c|c|c|c|c|}
\hline Item & $\begin{array}{c}\text { Pretest } \\
\text { mean }\end{array}$ & $\begin{array}{c}\text { Posttest } \\
\text { mean }\end{array}$ & $\begin{array}{c}t \\
\text { score }\end{array}$ & $\begin{array}{l}p \text { - } \\
\text { value }\end{array}$ & $\begin{array}{c}\text { Cohen's } \\
d\end{array}$ \\
\hline 4-H CMIS & 12.95 & 15.20 & 2.90 & .009 & .64 \\
\hline 1. I am good at science & 1.95 & 2.33 & 2.02 & .03 & .45 \\
\hline $\begin{array}{l}\text { 2. I would like to have a job } \\
\text { related to science }\end{array}$ & 1.95 & 2.30 & 1.68 & .055 & .38 \\
\hline $\begin{array}{l}\text { 3. I like doing science lab } \\
\text { procedures }\end{array}$ & 2.52 & 2.90 & 2.17 & .02 & .48 \\
\hline $\begin{array}{l}\text { 4. I can use scientific data to form } \\
\text { a question }\end{array}$ & 2.19 & 2.62 & 1.69 & .05 & .38 \\
\hline $\begin{array}{l}\text { 5. I can design a scientific } \\
\text { procedure to answer a question }\end{array}$ & 2.10 & 2.48 & 2.02 & .03 & .45 \\
\hline $\begin{array}{l}\text { 6. I can use data to create a graph } \\
\text { for presentation to others }\end{array}$ & 2.33 & 2.81 & 1.87 & .04 & .42 \\
\hline
\end{tabular}

Note. Range scores used were 1 (strongly disagree) to 4 (strongly agree); higher scores indicate a more favorable response. $\mathrm{CMIS}=$ National 4-H Common Measures Instrument for Science 1.0.

\section{Discussion and Implications}

The study described in this article reports on the ability of a brief 4- $\mathrm{H}$ intervention to alter the self-efficacy and task values related to STEM activities among a group of Latino early adolescents. Workshop activities were aimed at promoting a real-world understanding of science through hands-on experiences and introducing the students to new technologies and potential career paths in science and technology.

Results indicate students' favorable ratings of STEM activities improved after having attended the 4-H STEM workshop (see Table 2). In particular, the increased interest in obtaining a job in science (item 2) is a persuasive indication the workshop could have some success in encouraging the Unidos students to pursue careers in STEM-related fields. Additionally, student items 1, 4, 5, and 6 suggest that the workshop significantly impacted student perceptions of their ability to be successful in science. Item 4 suggests that students' enjoyment of sciencerelated activities increased as well. 
STEM Workshops and Interest Among Latino Youth

The expectancy value theory of achievement-related choices asserts that students' decisions to enroll in math and science courses are determined by how successful they believe they will be, and the value the students assign to the available options (Eccles et al., 1983). Exposing Latino students to new STEM-related experiences in an enjoyable format seems to increase their estimation of their future success in science.

Participation in the 4-H STEM Institute increased the Latino students' perceived self-efficacy in science and STEM skills. The students also indicated an increased interest in STEM career fields. The students' increase in self-efficacy predicts the students will increase their persistence in the subjects of science and math (Simpkins et al., 2006). Increased persistence in science and math leads to increased success in post-secondary STEM studies and occupations.

The present study suggests purposefully adding hands-on activities typical of 4-H programs may function as a catalyst to stimulate the interest of underrepresented Latino youth in STEMrelated fields. Other studies have shown the benefit of Unidos in promoting academic performance and enrollment in secondary education (Cox, 2017). The results of this study also indicate exposing Latino youth to Latino role models working in STEM fields increases the youths' interest in STEM. If our findings can be replicated in other studies, these findings indicate significant progress in the endeavor to increase minority representation in STEM professions. This study was limited to a small sample size but is highly replicable. Similar educational events could be measured for comparable results and findings.

The 4-H program operates under three mission mandates: citizenship, science, and healthy living. These mission mandates serve as the educational foundation for all 4-H educational programming (4-H National Headquarters, 2011). First- and second-generation Latino youth can benefit from these educational mandates, especially the science mandate. Latino youth are a significant segment of the population who are often underserved by 4-H programming. These youth potentially can fill a portion of the STEM pipeline if they are exposed to the everexpanding career options in STEM. By reaching out to this population, 4-H practitioners will be serving a new audience and potentially reaching the 4-H mandates through innovative and exciting programming.

In order to succeed in engaging Latino youth and their families, 4-H practitioners must also be aware this audience will not respond to their efforts like traditional 4-H audiences. First- and second-generation Latino youth and families have unique culture-based needs and preferences. Practitioners must be willing to approach them personally and search for new methods of 
STEM Workshops and Interest Among Latino Youth

connecting with the youth and their families. Family members may not speak English or be able to complete the standard 4-H enrollment and release forms or other paperwork on their own. However, this need not be a barrier. In a different study, our team demonstrated how creating a welcoming environment to Latino families can overcome language barriers (Alexander, Cox, Behnke, \& Larzelere, 2017). As a result of an often adverse political climate Latino families in general and immigrant families in particular are difficult to recruit into programs. Our work suggests 4-H practitioners should first establish relationships with trusted community members such as a school family liaison, priest, or service provider to help bridge the gap between cultures and promote recruitment (Cox, 2017). "Word-of-mouth" travels fast in Latino communities that frequently lack other means of discovering beneficial activities for their youth. Practitioners are encouraged to start small and slowly gain the trust of the community through persistently providing a quality service.

Latino families may not be connected digitally, which may require special accommodations. First- and second-generation Latino families also may have limited resources, which will require the practitioners to provide additional funding for $4-\mathrm{H}$ participation. These barriers can be overcome with an awareness of their existence. In our project, success coaches provided many of the bridges necessary to cross these barriers. We recommend that 4-H practitioners work with schools, counselors, and community leaders to reach Latino youth. In many cases these youth are overlooked due to the associated challenges. The 4-H program can provide a valuable service to these youth and to our society by making the extra effort to include first- and second- generation Latinos.

Because many practitioners will not have easy access to a major university, we encourage 4-H practitioners to use this study more as a template than as a prescription. Another way in which the Unidos Se Puede program promotes engagement in STEM activities is through developing relationships with existing community resources, such as local technology institutes and community colleges, museums, parks, independent businesses, and state and local government agencies. For example, we partnered with the Tulsa County Sheriff's department to expose Latino youth to the science involved in law enforcement. During a half-day activity youth learned about diverse forensics used in solving crimes, the K9 unit and the science behind how animals are trained and how they are used by law enforcement, and advanced tactical equipment used by police. These activities represent a "win-win" because law enforcement and other organizations are often interested in exposing youth to their institution as a way to build a pipeline that will increase minorities in their workforce and improve community relations. What our study ultimately shows is that exposing youth to STEM-related fields while allowing them to 
form social bonds with other youth is key to altering values and beliefs about a future career in math- or science-related fields.

\section{Limitations and Conclusion}

There are several limitations to this study that merit mentioning. First, although the study uses a pre-post format, the lack of a control group suggests caution when interpreting the results. Other factors such as a selection bias could account for some of the significant pre to post mean differences. However, because we found significant results despite our small sample size, this suggests robust findings, if causally related to the intervention. That is, exposing underserved Latino youth to STEM activities on a major college campus has a significant effect on their STEM-related self-efficacy and attitude toward pursuing a career in science. Relatedly, the small sample size from a single geographic location limits the generalizability of our findings. Finally, the findings of this study, although positive, cannot be assumed to translate into actual changes in behavior. Further long-term follow-up studies are needed to test how this intervention translates to course choices subsequent post-secondary enrollment among Latino youth.

Notwithstanding these limitations, this study represents a first test of a brief intervention with Latino immigrant youth. Due to the significant growth of Latino populations, minority participation in STEM careers is paramount to maintaining America's ability to compete globally in the ever-increasing need for STEM employees (Hagedorn \& Purnamasari, 2012; Litow, 2008; Rochin \& Mello, 2007; Scott, 2010). The lack of minorities in STEM disciplines seemingly is not due to a lack of interest, but to lack of exposure through positive hands-on experiences. Ensuring student readiness for postsecondary STEM programs requires exposure to appropriate course content in high school (Lynch, 2011). Latino students have the same attitudes as other students toward career options in math and science (Arbona \& Nora, 2007).

Brief, hands-on experiences in STEM could be the key to expanding minority students' exposure to STEM course content, drawing them into post-secondary STEM studies, and ultimately STEM career fields. Experiential, minority-targeted programs, similar to this one, support America's growing demand for STEM professionals. 


\section{Acknowledgements}

The writing of this article was made possible by funding from the U.S. Department of Agriculture, National Institute of Food and Agriculture, Children Youth and Families at Risk Grant (2013-41520-21026), and the National Institute of General Medicine (grant 1 P20 GM109097-01 A1), and the George Kaiser Family Foundation.

\section{References}

Alexander, J. D., Cox Jr, R. B., Behnke, A., \& Larzelere, R. E. (2017). Is all parental "noninvolvement" equal? Barriers to involvement and their relationship to Latino academic achievement. Hispanic Journal of Behavioral Sciences, 39(2), 169-179. doi:10.1177/0739986317700837

Arbona, C., \& Nora, A. (2007). The influence of academic and environmental factors on Hispanic degree attainment. The Review of Higher Education, 30(3), 247-269.

Archer, L., Dewitt, J., Osborne, J., Dillon, J., Willis, B., \& Wong, B. (2010). "Doing" science versus "being" a scientist: Examining 10/11-year-old schoolchildren's constructions of science through the lens of identity. Science Education, 94(4), 617-639. doi:10.1002/sce.20399

Archer, L., Hollingworth, S., \& Halsall, A. (2007). "University is not for me-I'm a Nike person": Urban, working-class young people's negotiations of "style," identity and educational engagement. Sociology, 41(2), 219-237. doi:10.1177/0038038507074798

Atkinson, R. D. \& Mayo, M. J. (2011). Refueling the US innovation economy: Fresh approaches to science, technology, engineering and mathematics (STEM) education. Washington, D.C. Information Technology and Innovation Foundation (ITIF), (pp 24-40). Retrieved September 1, 2012, from http://www.itif.org/files/2010-refueling-innovation-economy.pdf

Cole, D., \& Espinoza, A. (2008). Examining the academic success of Latino students in science technology engineering and mathematics (STEM) majors. Journal of College Student Development, 49(4), 285-300.

Cooper, C. R. (2011). Bridging multiple worlds: Cultures, identities, and pathways to college. New York, NY: Oxford University Press.

Cox, R. B., Jr. (2017). Promoting Resilience with thei Unidos Se Puede! Program: An Example of Translational Research for Latino Families. Family Relations, 66(4), 712-728. doi:10.1111/fare. 12265

Crisp, G., \& Nora, A. (2012). Overview of Hispanics in science, mathematics, engineering and technology (STEM): $K$-16 representation, preparation and participation. Retrieved from Hispanic Association of Colleges and University website: 
STEM Workshops and Interest Among Latino Youth

http://www.hacu.net/images/hacu/OPAI/H3ERC/2012_papers/Crisp\%20nora\%20\%20hispanics\%20in\%20stem\%20-\%20updated\%202012.pdf

Eccles, J. S. (2009). Who am I and what am I going to do with my life? Personal and collective identities as motivators of action. Educational Psychologist, 44(2), 78-89. doi:101080/00461520902832368

Eccles, J. S., Adler, T. F., Futterman, R., Goff, S. B., Kaczala, C. M., Meece, J. L., \& Midgley, C. (1983). Expectations, values and academic behaviors. In J. T. Spence (Eds.), Perspectives on achievement and achievement motivation (pp. 75-146). San Francisco, CA: W. H. Freeman.

Eccles, J. S., Wigfield, A., \& Schiefele, U. (1997). Motivation to succeed. In W. Damon \& N. Eisenberg (Eds.). Handbook of child psychology (Vol. 3, $5^{\text {th }}$ ed., pp. 1017-1095). New York, NY: Wiley.

Fouad, N. A., \& Smith, P. L. (1996). A test of a social cognitive model for middle school students: Math and science. Journal of Counseling Psychology, 43(3), 338-346. doi:10.1037/0022-0167.43.3.338

4-H National Headquarters. (2011). Mission mandates [Fact Sheet]. Retrieved from https:nifa.usda.gov/sites/default/files/resource/4-H Mission Mandates.pdf

Frank, K. A., Muller, C., Schiller, K. S., Riegle-Crumb, C., Mueller, A. S., Crosnoe, R., \& Pearson, J. (2008). The social dynamics of mathematics course taking in high school. American Journal of Sociology, 113, 1645-1696. doi:10.1086/587153

Hagedorn, L. S., \& Purnamasari, A. V. (2012). A realistic look at STEM and the role of community colleges. Community College Review, 145-164. doi:10.1177/0091552112443701

Hines, S. M. (2003). Multicultural science education: Theory, practice, and promise. New York, NY: Peter Lang.

Johnson, H., \& Sengupta, R. (2009). Closing the gap: Meeting California's needs for college graduates. San Francisco, CA: Public Policy Institute of California.

Landivar, L. C. (2013). Disparities in STEM employment by sex, race, and Hispanic origin. United States Census Bureau.

Litow, S. (2008, July 21). A silent crisis: The underrepresentation of Latinos in STEM careers. Education Week. Retrieved from https://www.edweek.org/ew/articles/2008/07/18/44litowcom_web.h27.html

Lynch, S. J. (2011). Equity and U.S. science education policy from the G.I. Bill to NCLB: From opportunity denied to mandated outcomes. In G. E. DeBoer (Ed.), The role of public policy in $K$ - 12 science education (pp. 305-354). Charlotte, NC: Information Age.

Mau, W. C. (2003). Factors that influence persistence in science and engineering career aspirations. Career Development Quarterly, 51(3), 234-243.

National Academy of Sciences. (2007). Rising above the gathering storm: Energizing and employing America for a brighter economic future. Washington, DC: National Academy Press. Retrieved September 1, 2011, from http://www.nap.edu/catalog.php?record_id=11463 
STEM Workshops and Interest Among Latino Youth

National Center for Education Statistics. (2011). High School Longitudinal Study: 2009 EDAT extract codebook. Washington, DC: Author. Retrieved October 10, 2011, from http://nces.ed.gov/surveys/hsls09/hsls09_data.asp

National Science Board. (2018). Science and engineering indicators (Policy Companion Brief No. NSB2018-7). Retrieved from https://www.nsf.gov/nsb/sei/companion-brief/NSB-2018-7.pdf

National Science Foundation. (2012). Women, minorities, and persons with disabilities in science and engineering [web page]. Retrieved November 10, 2012, from http://www.nsf.gov/statistics/wmpd/2013/race.cfm

Navarro, R. L., Flores, L. Y., \& Worthington, R. L. (2007). Mexican American middle school students' goal intentions in mathematics and science: A test of social cognitive career theory. Journal of Counseling Psychology, 54, 320-335. doi:10.1037/0022-0167.54.3.320

Rice, J. E., Rugg, B., \& Davis, S. (2016). Minnesota 4-H science and agriculture challenge: Infusing agricultural science and engineering concepts into 4-H youth development. Journal of Extension, 54(3), Article 3IAW4. Retrieved from https://www.joe.org/joe/2016june/iw4.php

Rochin, R. I., \& Mello, S. F. (2007). Latinos in science: Trends and opportunities. Journal of Hispanic Higher Education, 305-355. doi:10.1177/1538192707306552

Sallee, J., \& Peek, G. (2014). Fitting the framework: The STEM Institute and the 4-H essential elements. Journal of Extension, 52(2), Article 2FEA8. Retrieved from http://www.joe.org/joe/2014april/a8.php

Scott, A. (2010). Dissecting the data: The STEM education opportunity gap in California. San Francisco, CA: Level Playing Field Institute.

Simpkins, S. D., Davis-Kean, P. E., \& Eccles, J. S. (2006). Math and science motivation: A longitudinal examination of the links between choices and beliefs. Developmental Psychology, 42(1), 70-83. doi:10.1037/0012-1649.42.1.70

Stake, J. E. (2006). The critical mediating role of social encouragement for science motivation and confidence among high school girls and boys. Journal of Applied Social Psychology, 36, 10171045.

Stake, J. E., \& Nickens, S. D. (2005). Adolescent girls' and boys' science peer relationships and perceptions of the possible self as scientist. Sex Roles, 52, 1-11. doi:10.1111/j.00219029.2006.00053.x

U.S. Department of Education. (2008). 2007 Elementary and secondary school survey. Washington, DC: Office for Civil Rights. 


\section{Appendix}

\section{Overview of the OSU Sponsored Unidos STEM Workshop}

Table A1. Animal Science Biotechnology Workshop Schedule

\begin{tabular}{|c|c|}
\hline Time & Animal Science Biotechnology Day 1 Activity \\
\hline $1: 00 p-2: 00 p$ & $\begin{array}{l}\text { Introductory Lecture: Biotechnology, scientific terminology \& cell to DNA } \\
\text { overview. } \\
\text { Lab Work: Use of air displacement pipet. Pipetting exercises. }\end{array}$ \\
\hline $2: 00 p-3: 00 p$ & $\begin{array}{l}\text { Lecture: Part } 1 \text { of DNA Isolation Experiment. } \\
\text { Lab Work: DNA Isolation. }\end{array}$ \\
\hline $3: 00 p-3: 45 p$ & $\begin{array}{l}\text { Lecture: Use of Biotechnology in Animal Science: Genotyping for breed } \\
\text { registry and introduction to PCR }\end{array}$ \\
\hline $3: 45 p-4: 30 p$ & Lab Work: Part 2 of DNA Isolation Experiment and PCR procedure \\
\hline $4: 30 p-5: 00 p$ & Lecture: DNA sequencing \\
\hline $5: 00 p-6: 00 p$ & Move into dorms \\
\hline $6: 00 p-8: 30 p$ & $\begin{array}{l}\text { Horse'n Around: Equine Tour \& Roping Demo. } \\
\text { Snack: Pizza }\end{array}$ \\
\hline $8: 30 p-11: 00 p$ & Return to dorms and relax \\
\hline 11:00p & Lights Out \\
\hline Time & Animal Science Biotechnology Day 2 Activity \\
\hline $8: 30 a$ & Breakfast \\
\hline 9:00a - 10:00a & $\begin{array}{l}\text { Tour of OSU Proteomics and DNA Core Facility - "Living in a time of } \\
\text { technological revolution" }\end{array}$ \\
\hline 10:00a - 12:00p & $\begin{array}{l}\text { Phenotype prediction activity: guessing parentage of horse and preparing } \\
\text { gels for electrophoresis }\end{array}$ \\
\hline $12: 00 p-4: 30 p$ & $\begin{array}{l}\text { Activity: Interpreting horse DNA profiles (All students). } \\
\text { Lecture: Use of DNA sequencing in agriculture and in other fields of study. } \\
\text { Lab Work: Results of DNA isolation using gel electrophoresis (gel } \\
\text { preparations and examination of previously processed gels). }\end{array}$ \\
\hline
\end{tabular}


STEM Workshops and Interest Among Latino Youth

Table A2. Digital Media Workshop Schedule

\begin{tabular}{|c|c|}
\hline Time & Digital Media Day 1 Activity \\
\hline $1: 00 p-2: 00 p$ & $\begin{array}{l}\text { Introduction: Digital Media Overview - Using your Camera/iPad for digital } \\
\text { media creation. } \\
\text { Video: Shot composition, planning, framing, lighting, perspective, and } \\
\text { showcasing. } \\
\text { Video: Camera Handling } \\
\text { Lab Work: Let's take some pictures! }\end{array}$ \\
\hline $2: 00 p-3: 00 p$ & $\begin{array}{l}\text { Lecture: Critical Response exercise: SAMS (Story Audience Message Style) } \\
\text { Lab Work: Reviewing Photography }\end{array}$ \\
\hline $3: 00 p-4: 00 p$ & $\begin{array}{l}\text { Lecture: Preproduction Telling your story: Sample Videos. } \\
\text { Lab Work: Windows Activity }\end{array}$ \\
\hline $4: 00 p-5: 00 p$ & Lecture: Conducting a Video Shoot \\
\hline $5: 00 p-6: 00 p$ & Move into dorms \\
\hline $6: 00 p-8: 30 p$ & $\begin{array}{l}\text { Horse'n Around: Equine Tour \& Roping Demonstration } \\
\text { Snack: Pizza }\end{array}$ \\
\hline $8: 30 p-11: 00 p$ & Return to dorms and relax \\
\hline $11: 00 p$ & Lights Out \\
\hline Time & Digital Media Day 2 Activity \\
\hline $8: 30 a$ & Breakfast \\
\hline $9: 00 a-10: 45 a$ & $\begin{array}{l}\text { Oklahoma Gardening Photography Tour } \\
\text { Botanic Gardens Tour Digital Media Exercise }\end{array}$ \\
\hline $10: 45 a-12: 00 p$ & Second Digital Media Tour Kicker Audio Museum \\
\hline $12: 00 p-4: 00 p$ & $\begin{array}{l}\text { Group Work } \\
\text { Digital Media: Creation/ Editing } \\
\text { Video: Editing, Rough Drafts \& Critiques } \\
\text { Video Showcase: All students create and present a video inspired by their } \\
\text { OSU experience using knowledge gained in the Digital Media track }\end{array}$ \\
\hline
\end{tabular}

